\title{
Effect of Dissolved Oxygen Tension on Production of Carotenoids, Poly- $\beta$-hydroxybutyrate, Succinate Oxidase and Superoxide Dismutase by Azospirillum brasilense Cd Grown in Continuous Culture
}

\author{
By ISRAEL NUR, YAACOV OKON* AND YIGAL HENIS \\ Department of Plant Pathology and Microbiology, Faculty of Agriculture, Hebrew University of \\ Jerusalem, P.O. Box 12, Rehovot 76 100, Israel
}

(Received 10 November 1981; revised 5 July 1982)

\begin{abstract}
Azospirillum brasilense strain $\mathrm{Cd}$ was grown in a medium containing $\mathrm{NH}_{4}^{+}$in a chemostat at a range of constant dissolved oxygen tensions (d.o.t.) (0.007-0.18 atm). Poly- $\beta$-hydroxybutyrate (up to $12 \%$ of the cell dry weight) increased under oxygen limitation and moderate dilution rate $\left(D=0.14 \mathrm{~h}^{-1}\right)$. The highest carotenoid content was observed at high d.o.t. and dilution rates up to $0.12 \mathrm{~h}^{-1}$. The amount of protein varied with d.o.t. from $0.29 \mathrm{mg}$ protein (mg dry wt) ${ }^{-1}$ at $0.007 \mathrm{~atm}$ to $0.54 \mathrm{mg}$ at $0.18 \mathrm{~atm}$. The yield efficiency and respiration rate were highest at low d.o.t. and decreased significantly at a d.o.t. of $0.18 \mathrm{~atm}$. Succinate dehydrogenase and malate dehydrogenase activities increased 2.5-fold at $0 \cdot 10-0.18$ atm $\mathrm{O}_{2}$, whereas succinate oxidase and NADH oxidase activities increased consistently with increasing d.o.t. Azospirillum brasilense showed a low specific activity for catalase; the specific activity of superoxide dismutase increased sharply above $0 \cdot 16$ atm $\mathrm{O}_{2}$.
\end{abstract}

\section{INTRODUCTION}

Although capable of aerobic growth, rhizosphere bacteria of the genus Azospirillum are capable of fixing molecular nitrogen only under low $\mathrm{pO}_{2}(0.005 \mathrm{~atm})$, probably because of the inactivation of nitrogenase by oxygen and its radicals (Okon et al., 1976a; Day \& Dobereiner, 1976; Nelson \& Knowles, 1978).

In recent studies (Nur et al., 1980; Okon et al., 1980), it was found that although $A$. brasilense was capable of growing at faster rates at high $\mathrm{pO}_{2}$ in the presence of $\mathrm{NH}_{4} \mathrm{Cl}$, if given the choice and in spite of the presence of combined nitrogen, $A$. brasilense actively sought microaerobic conditions, i.e. it developed as a pellicle below the surface in semi-solid medium or it entered capillaries containing only water or phosphate buffer, forming a band which moved towards a decreasing $\mathrm{pO}_{2}$ gradient (aerotaxis to low $\mathrm{pO}_{2}$ ). When grown on $\mathrm{N}_{2}$ at low $\mathrm{pO}_{2}$, A. brasilense strain $\mathrm{Sp} 7$ formed poly- $\beta$-hydroxybutyrate (PHB) which amounted to about $30 \%$ of the cell dry weight, whereas in cells growing under high $\mathrm{pO}_{2}$ in the presence of $\mathrm{NH}_{4} \mathrm{Cl}, \mathrm{PHB}$ formed less than $1 \%$ of the cells weight (Okon et al., 1976b). Nur et al. (1981) reported that red-pigmented $A$. brasilense strain Cd produced carotenoids, apparently involved in the protection of $A$. brasilense $\mathrm{Cd}$ nitrogenase from $\mathrm{O}_{2}$. Carotenoid synthesis started in liquid static cultures only after the concentration of $\mathrm{NH}_{4} \mathrm{Cl}$ in the medium had decreased and $\mathrm{N}_{2}$-fixation became evident. Carotenoid synthesis did not occur under microaerobic conditions. When carotenoid synthesis was specifically inhibited in the presence of diphenylamine, the rate of acetylene reduction in strain Cd decreased by $50 \%$.

Carbon-limited chemostat cultures of $A$. brasilense $\mathrm{Sp} 7$ have bean studied on $\mathrm{N}$-free medium at various dissolved oxygen concentrations (Nelson \& Knowles, 1978). In this work we report the behaviour of $A$. brasilense $\mathrm{Cd}$ in the presence of $\mathrm{NH}_{4} \mathrm{Cl}$ in a chemostat, under different dissolved $\mathrm{O}_{2}$ concentrations and different dilution rates.

Abbreviations: d.o.t., dissolved oxygen tension(s); PHB, poly- $\beta$-hydroxybutyrate. 


\section{METHODS}

Organism and growth conditions. Stock cultures of Azospirillum brasilense strain Cd, ATCC 29729 (Tarrand et al., 1978), were maintained on $\mathrm{N}$-free malate medium (Okon et al., 1977). To propagate a continuous culture, a bench chemostat (New Brunswick, NBS model C30) of 1.51 working capacity was used. Dissolved oxygen tensions (d.o.t.) were measured with an autoclavable galvanic-type electrode (NBS model M1016-0208). The oxygen probe was calibrated initially by passing pure nitrogen and then air through the stirred uninoculated growth vessel. D.o.t. values were kept constant during growth with a sterile mixture of nitrogen and air, the composition of which was varied automatically by an NBS oxygen controller (Model DO-80). The culture was stirred at a constant rate of 300 r.p.m. Growth temperature was maintained at $30^{\circ} \mathrm{C}$.

The mineral growth medium containing potassium phosphate buffer (pH 6.8) (Okon et al., 1977) was supplemented with $2 \mathrm{~g}$ malic acid, $0.8 \mathrm{~g} \mathrm{NaOH}$ and $0.5 \mathrm{~g} \mathrm{NH}_{4} \mathrm{Cl}$ per litre. The $\mathrm{pH}$ of the medium was kept at pH 6.8 throughout the experiment by an NBS pH controller (model pH-22).

Inocula were prepared by growing cultures at $30^{\circ} \mathrm{C}$ on a rotary shaker in $250 \mathrm{ml}$ Erlenmeyer flasks containing $100 \mathrm{ml}$ malate medium supplemented with $0.5 \mathrm{~g} \mathrm{NH}_{4} \mathrm{Cl} \mathrm{l}^{-1}$. Bacterial growth was measured either turbidimetrically with a Junior II Coleman spectrophotometer or by determining bacterial dry weight. Bacterial suspensions $(20 \mathrm{ml})$ were centrifuged at $7000 \mathrm{~g}$ for $10 \mathrm{~min}$ at $4{ }^{\circ} \mathrm{C}$. The pellet was resuspended in $5 \mathrm{ml}$ distilled water, and dried at $80^{\circ} \mathrm{C}$ for $24 \mathrm{~h}$. The relation between bacterial dry weight and $A_{420}$ was constant at all dry weight values: dry weight $\left(\mathrm{mg} \mathrm{ml}^{-1}\right)=1 \cdot 180 A_{420}$ (S.D. $\left.\pm 0 \cdot 05\right)$.

Analytical procedures. Total dissolved carbon in the culture medium was determined by the dichromate method (Johnson, 1949). Cell extracts were obtained by sonication $\left(5 \mathrm{~min}\right.$ at $4^{\circ} \mathrm{C}$ ) using an MSE ultrasonic disintegrator or by overnight extraction with $0.5 \mathrm{M}-\mathrm{NaOH}$ (for determination of protein). The protein content of extracts was determined by a modification of Lowry's procedure (Markwell et al., 1979) using bovine serum albumin (Sigma) as a standard.

Bacterial carotenoids were extracted and determined as described previously (Nur et al., 1981), using an absorption coefficient of 2500 at $500 \mathrm{~nm}$ for a $1 \%(\mathrm{w} / \mathrm{v})$ solution (Stern et al., 1964).

The poly- $\beta$-hydroxybutyrate content of $A$. brasilense was determined by the modified method of Senior $e t$ al. (1972). Each point was determined in six replicates (S.E. $<10 \%$ ).

Enzyme activities. All assays were done at $30^{\circ} \mathrm{C}$. Oxygen consumption was followed polarographically, using a biological oxygen monitor (model 53; Yellow Springs Instrument Co., Yellow Springs, Ohio, U.S.A.). The potential respiration rate of bacteria growing in the chemostat was determined as follows. Samples taken from the growth vessel were rapidly diluted in $0.1 \mathrm{M}$-potassium phosphate buffer $(\mathrm{pH} 7 \cdot 2)$. The respiratory activity of the buffer-suspended cells was measured immediately at $30^{\circ} \mathrm{C}$, both in the absence and in the presence of sodium malate (final concentration $0.2 \mathrm{M}$ ). Activity was expressed as $\mu \mathrm{l} \mathrm{O}_{2}$ consumed $\mathrm{h}^{-1}(\mathrm{mg} \text { dry wt) })^{-1}$.

Crude extracts of $A$. brasilense $\mathrm{Cd}$ grown at various d.o.t. values were obtained by sonicating buffer-washed cells for $5 \mathrm{~min}$ at $4{ }^{\circ} \mathrm{C}$. The extract was centrifuged at $17000 \mathrm{~g}$ for $20 \mathrm{~min}$ at $4{ }^{\circ} \mathrm{C}$, and the supernatant was diluted to $2-$ $3 \mathrm{mg}$ protein $\mathrm{ml}^{-1}$.

The rate of oxygen uptake by extracts was estimated by a modification of the method of Stone \& Wilson (1952). The reaction mixture contained $1 \mathrm{ml} \mathrm{0.2} \mathrm{M}$-potassium phosphate buffer, $\left(\mathrm{pH} \mathrm{7 \cdot 0}\right.$ ), containing $0.02 \mathrm{M}-\mathrm{MgSO}_{4}, 1 \mathrm{ml}$ extract, and succinate and/or NADH at final concentrations of $40 \mathrm{mM}$, and $12.2 \mathrm{mM}$, respectively.

Malate dehydrogenase and succinate dehydrogenase were assayed by procedure of Courtright \& Henning (1970).

Superoxide dismutase was assayed as described by Buchanan \& Leeds (1976). One unit of enzyme was defined as the amount of enzyme giving $50 \%$ inhibition of the rate of reduction of cytochrome $c$. Catalase was estimated by the conventional polarographic oxygen electrode method, to determine the production of oxygen from $10 \mu \mathrm{mol} \mathrm{H}_{2} \mathrm{O}_{2}$ in $1 \mathrm{~min}$, after correction with the appropriate controls. Increasing the quantity of $\mathrm{H}_{2} \mathrm{O}_{2}$ or the time of incubation resulted in a decrease of the enzyme activity due to its inactivation by the substrate.

\section{RESULTS}

\section{Effect of dissolved oxygen tension on growth parameters}

The growth of $A$. brasilense $\mathrm{Cd}$ in the presence of $\mathrm{NH}_{4} \mathrm{Cl}$ at a constant dilution rate (generation time $8.66 \mathrm{~h}$ ) was followed under various d.o.t. conditions ranging from air saturation (d.o.t. $=0.21 \mathrm{~atm}$ ) to oxygen-limiting conditions (Fig. 1). Cell mass (dry weight) increased rapidly from $0.525 \mathrm{mg} \mathrm{ml}^{-1}$ at $0.015 \mathrm{~atm}$, reaching a steady state that was maintained over a wide range of d.o.t. $(0 \cdot 015-0 \cdot 18 \mathrm{~atm})$. The cell mass of air-saturated cultures was significantly lower (Fig. 1 a). At low d.o.t. $(0.007 \mathrm{~atm})$, the protein content of the cells was low, but it increased at d.o.t. $=0.03 \mathrm{~atm}$ and remained constant at d.o.t. values up to $0.125 \mathrm{~atm}$. At higher d.o.t. values protein content increased in spite of a decrease in cell mass (Fig. $1 a$ ). 


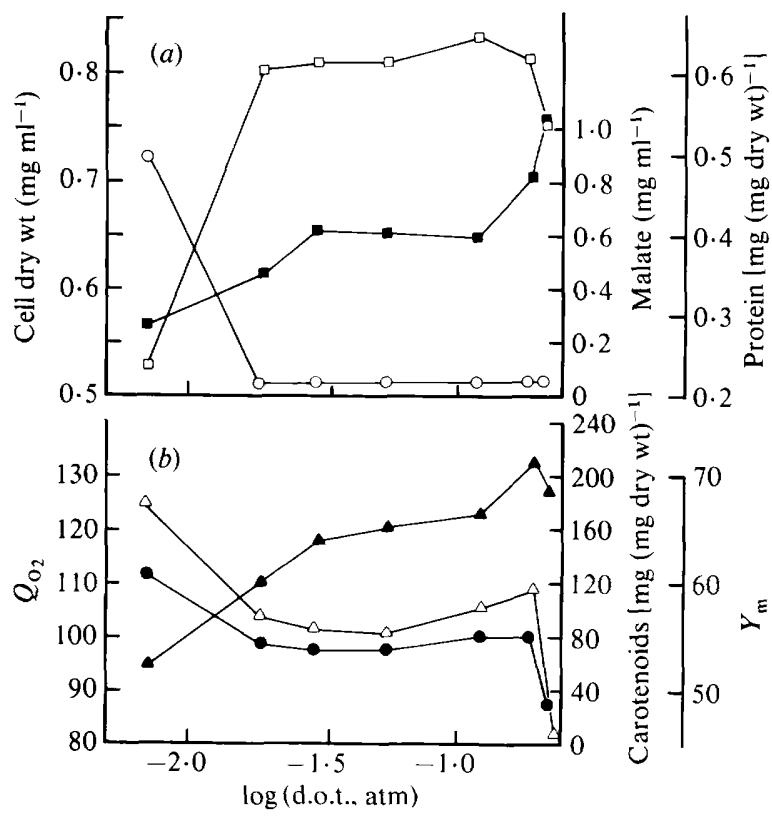

Fig. 1. Growth of $A$. brasilense $\mathrm{Cd}$ in continuous culture with $0.5 \mathrm{~g} \mathrm{NH}_{4} \mathrm{Cl}^{-1}$, at different dissolved oxygen tensions $(0.007$ to $0.21 \mathrm{~atm})$. $\square$, Bacterial dry weight; $\square$, protein content; $O$, malate in culture supernatant;,$\left.Y_{\mathrm{m}}[\mathrm{g} \text { cells (mol malate utilized) })^{-1}\right] ; \triangle, Q_{\mathrm{O}_{2}}\left[\mu \mathrm{l} \mathrm{O} \mathrm{h}^{-1}(\mathrm{mg} \text { dry wt })^{-1}\right] ; \Delta$, carotenoid content. The dilution rate was $0.08 \mathrm{~h}^{-1}$.

There was a direct relationship between the carotenoid content of the cells and the d.o.t. of the growth medium. However, under air-saturated conditions there was a small decrease in carotenoid content (Fig. $1 b$ ). $Q_{\mathrm{O}_{2}}$ values $\left[\mu \mathrm{IO}_{2} \mathrm{~h}^{-1}\left(\mathrm{mg}\right.\right.$ dry wt) $\left.{ }^{-1}\right]$, malate yield coefficients $Y_{\mathrm{m}}[\mathrm{g}$ organism formed ( $\mathrm{mol}$ malate utilized $\left.)^{-1}\right]$ and residual malate concentration were also measured (Fig. $1 a, b$ ). The $Q_{\mathrm{O}_{2}}$ and $Y_{\mathrm{m}}$ values decreased with increasing d.o.t., reaching a plateau at d.o.t. $=0.03 \mathrm{~atm}$. In air-saturated cultures, $Q_{\mathrm{O}_{2}}$ and $Y_{\mathrm{m}}$ values were markedly lower (Fig. $1 b$ ). There was a direct relationship between $Q_{\mathrm{O}_{2}}$ and $Y_{\mathrm{m}}$ throughout all $\mathrm{O}_{2}$ concentrations (Fig. $1 b$ ). It should be noted that these results differ from those reported by Senior et al. (1972) and Ward et al. (1977), who observed in Azotobacter beijerinckii an inverse relation between $Q_{\mathrm{O}_{2}}$ and yield, due probably to the uncoupling of the electron transport system at high $\mathrm{O}_{2}$ concentration.

The highest residual malate concentration was observed at d.o.t. $=0.007 \mathrm{~atm}$, but at all other d.o.t. values the residual concentration was very low (Fig. $1 a$ ), which indicated that oxygen limitation occurred only at $0.007 \mathrm{~atm}$ at the dilution rate used.

\section{Effect of d.o.t. on cell mass and growth rate}

The maximum biomass obtained under steady-state conditions in the chemostat was $0.84 \mathrm{mg} \mathrm{ml}^{-1}$. Limiting $\mathrm{O}_{2}$ concentration, either by lowering d.o.t. in the growth chamber or by increasing the dilution rate, led to a decrease in cell concentration.

Generally, bacterial biomass in carbon-limited Azospirillum cultures remained constant at all the dilution rates tested. However, when oxygen limitation was imposed an initial decrease in bacterial concentration was followed by readjustment to the new environment resulting in a new steady state (Fig. 2).

\section{Effect of d.o.t. and dilution rate on carotenoids and $P H B$}

The maximum specific carotenoid content, $0.57 \mu \mathrm{g}(\mathrm{mg} \text { protein })^{-1}$, was observed at d.o.t. $=$ $0.18 \mathrm{~atm}$ and at dilution rates up to $0.12 \mathrm{~h}^{-1}$; at higher dilution rates it decreased rapidly to $0.2 \mu \mathrm{g}$ (mg protein $)^{-1}$ (Fig. 3), suggesting that carotenoid synthesis occurs mainly at low growth 


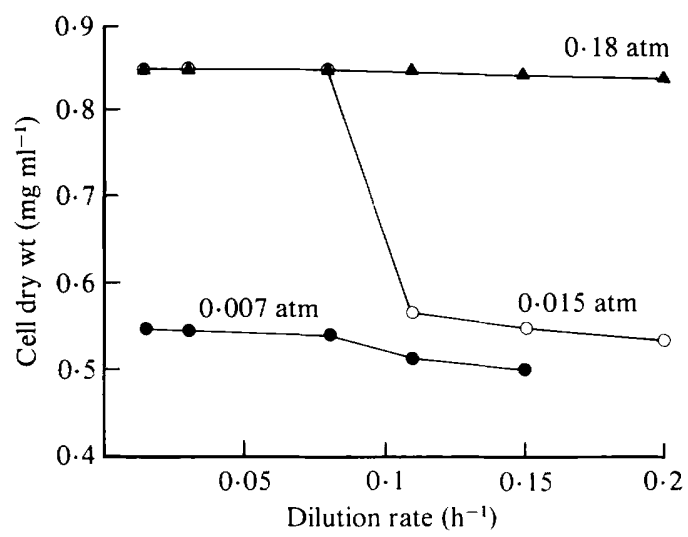

Fig. 2. Variation of steady-state biomass with growth rate in a malate-limited chemostat culture at three different dissolved oxygen concentrations: $\mathbf{\Delta}, 0.18 \mathrm{~atm} ; 0,0.015 \mathrm{~atm} ; 0,0.007 \mathrm{~atm}$. For experimental details see text.

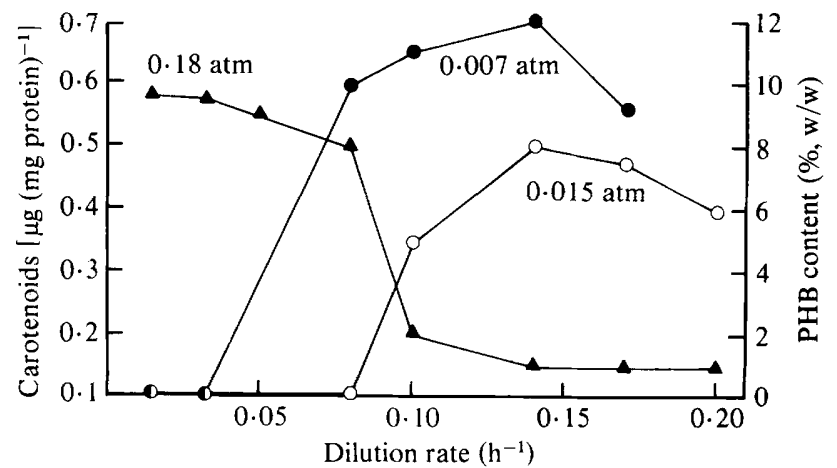

Fig. 3. Variation in carotenoid and $\mathrm{PHB}$ content with dilution rate. $\mathbf{A}$, carotenoid content at $0 \cdot 18 \mathrm{~atm}$; $\mathrm{O}$, PHB content at $0 \cdot 015 \mathrm{~atm} ; \boldsymbol{O}$, PHB content $0.007 \mathrm{~atm}$ (PHB was not detected at $0 \cdot 18 \mathrm{~atm}$ ). For experimental details see text.

rates and when oxygen is not a limiting factor. Maximum PHB content ( $12 \%$ of the biomass) was observed under microaerobic conditions and at moderate growth rates (Fig. 3).

\section{Effect of d.o.t. on enzyme activities}

NADH oxidase and succinate oxidase activities increased in proportion to the d.o.t. of the medium (Fig. 4a). In contrast, succinate and malate dehydrogenase activities increased markedly only above $0 \cdot 16 \mathrm{~atm}$ (Fig. $4 \mathrm{~b}$ ). Superoxide dismutase activity increased slightly as d.o.t. was increased to intermediate levels. A sharp increase in superoxide dismutase activity, reaching a maximum of 72 units (mg dry wt) $)^{-1}$, was obtained at d.o.t. above $0 \cdot 16$ atm (Fig. 5). Catalase activities were generally low, and decreased with increasing d.o.t. (Fig. 5).

\section{DISCUSSION}

In this work we present further evidence on the capability of Azospirillum brasilense Cd, growing under steady state conditions in the chemostat, to adapt readily to different d.o.t. values and dilution rates.

As shown by the higher $Y_{\mathrm{s}}\left(Y_{\mathrm{m}}\right)$ values obtained under low $\mathrm{pO}_{2}$ and low dilution rates, conditions generally encountered in the rhizosphere, $A$. brasilense $\mathrm{Cd}$ utilized its energy and carbon sources more efficiently. Similarly, high $\mathrm{N}_{2}$ fixation efficiencies [i.e. $\mathrm{mg} \mathrm{N}$ fixed (g 


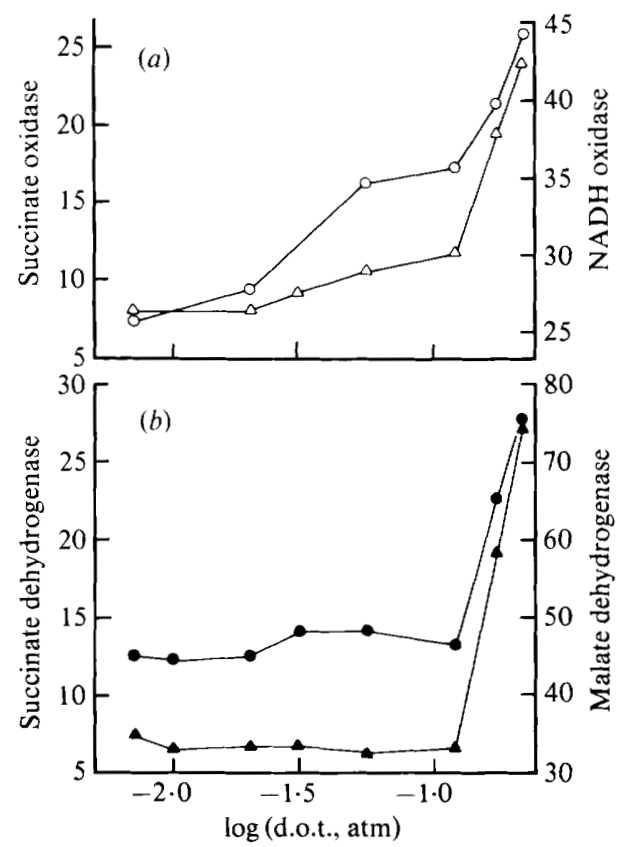

Fig. 4. Effect of variation in d.o.t., in a chemostat culture of $A$. brasilense $\mathrm{Cd}$, on the activities of NADH oxidase $\left[\mu \mathrm{O}_{2} \mathrm{~h}^{-1}(\mathrm{mg} \text { dry } w \mathrm{t})^{-1}, \mathrm{O}\right]$, succinate oxidase $\left[\mu \mathrm{l} \mathrm{O} \mathrm{h}^{-1}(\mathrm{mg} \text { dry wt })^{-1}, \triangle\right]$, malate dehydrogenase [nmol NADH $\left.\min ^{-1}\left(\mathrm{mg}^{\mathrm{N} y \mathrm{wt}}\right)^{-1}, \mathrm{O}\right]$ and succinate dehydrogenase [nmol succinate $\min ^{-1}(\mathrm{mg} \mathrm{dry} \mathrm{wt})^{-1}, \boldsymbol{\Delta}$ ]. Details as for Fig. 1 .

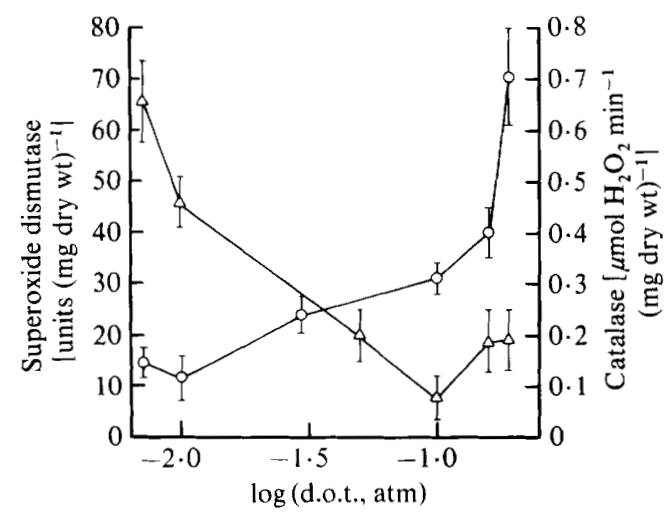

Fig. 5. Effect of different dissolved oxygen tensions on superoxide dismutase $(O)$ and catalase $(\triangle)$ activities in a chemostat culture of $\boldsymbol{A}$. brasilense $\mathrm{Cd}$. Details as in Fig. 1. Standard deviation bars are shown.

carbon substrate utilized) $)^{-1}$ ] have been observed at microaerobic conditions under limited malate supply (Day \& Döbereiner, 1976; Okon et al., 1976a). In addition, under these conditions, $A$. brasilense produced PHB in larger quantities, $12 \%$ in strain Cd (Fig. 4) and $30 \%$ in strain Sp7 in batch cultures (Okon et al., 1976b). PHB may serve as further energy and carbon source when carbon is limiting; high hydroxybutyrate dehydrogenase activities were observed under low $\mathrm{pO}_{2}$ (Okon et al., 1976b), and this corroborates the relationship between oxygen limitation and PHB accumulation observed in other $\mathrm{N}_{2}$-fixing organisms grown on $\mathrm{NH}_{4}$ or $\mathrm{N}_{2}$ (Ward et al., 1977).

At intermediate d.o.t. values $\boldsymbol{A}$. brasilense $\mathrm{Cd}$ produced red carotenoids, which are apparently capable of protecting the cell against oxidative damage, because of their ability to quench singlet oxygen and possibly oxygen radicals (Krinsky, 1979). In addition, carotenoids may act as a rigid 
insert reinforcing the membrane bilayer (Rottem \& Markowitz, 1979) thus reducing $\mathrm{O}_{2}$ diffusion into the cytoplasm. In this work, a clear relationship was observed between carotenoid content in $A$. brasilense $\mathrm{Cd}$ and oxygen concentration. The same relationship was obtained under $\mathrm{N}_{2}$-fixing conditions in batch cultures (Nur et al., 1981).

Under high d.o.t. and/or high dilution rates (conditions difficult, but not impossible to find in the rhizosphere) production of PHB was markedly decreased (Fig. 4, and Okon et al., 1976b). At high oxygen concentrations, carotenoid content may be reduced either by inhibition of synthesis or as a result of destruction by oxygen radicals. When exposed to air, purified $A$. brasilense $\mathrm{Cd}$ carotenoids were rapidly destroyed (Nur et al., 1981).

Under d.o.t. and high dilution rates PHB and carotenoid production were inhibited. In contrast, the protein content of the cells, and the specific activities of succinic dehydrogenase and succinic oxidase, increased under high d.o.t. Succinic dehydrogenase is an FAD membranebound enzyme found as a complex with cytochrome $b$ in $E$. coli, a Bacillus species (Hendler \& Burgess, 1974) and A. brasilense (Y. Okon \& R. H. Burris, unpublished results). This system may protect the bacterium by scavenging oxygen in a way similar to the protective oxidase system, reported recently by Bergersen \& Turner (1980) in Rhizobium bacteroids and in Azospirillum brasilense $\mathrm{Sp} 7$.

Superoxide dismutase activity of $\boldsymbol{A}$. brasilense $\mathrm{Cd}$ was induced under increased d.o.t., but catalase activity was relatively weak, especially at high d.o.t. values, when its function is probably most needed. Stouthamer et al. (1979) suggested that under atmospheric oxygen pressure, the respiratory system of microaerophilic bacteria was organized in such a way that large amounts of toxic oxygen metabolites are formed during respiration, and that the activity of enzymes of decomposition of $\mathrm{O}_{2}^{-}$and $\mathrm{H}_{2} \mathrm{O}_{2}$ was unsufficient to prevent damage to the cell. This may apply also to $A$. brasilense. However, in this bacterium the damage did not affect the respiratory enzymes (see Fig. $3 a, b$ ) but affected the intact cell respiration and yield efficiency (see Fig. $1 b$ ). Although $A$. brasilense Cd contains protecting agents (such as carotenoids) against oxygen and its radicals it still actively seeks, by aerotaxis (Okon et al., 1980), an environment where oxygen is limiting (microaerobic environment); this behaviour is probably less costly in energy terms than the synthesis of carotenoids or respiration enzymes. Therefore $A$. brasilense differs significantly from Azotobacter beijerinckii which possesses high catalase activity and is capable of fixing $\mathrm{N}_{2}$ under high d.o.t.

The research was supported by the USA-Israel Binational Foundation (BSF), Jerusalem, Israel, grant no. $2476 / 81$.

\section{REFERENCES}

Bergersen, F. J. \& Turner, G. L. (1980). Properties of terminal oxidase systems of bacteroids from roots of soybean and cowpea and of $\mathbf{N}_{2}$-fixing bacteria grown in continuous culture. Journal of General Microbiology 118, 235-252.

Buchanan, A. G. \& Lees, H. (1976). The effects of pH and temperature on the assays of superoxide dismutase. Canadian Journal of Microbiology 22, 16431646.

Courtright, J. B. \& Henning, U. (1970). Malate dehydrogenase mutants in Escherichia coli K-12. Journal of Bacteriology 102, 722-728.

DAY, J. M. \& Döbereiner, J. (1976). Physiological aspects of $\mathrm{N}_{2}$-fixation by a Spirillum from Digitaria roots. Soil Biology and Biochemistry 8, 45-50.

JoHNSON, M. J. (1949). A rapid micromethod of estimation of non-volatile organic matter. Journal of Biological Chemistry 181, 707-711.

HendleR, R. W. \& Burgess, A. H. (1974). Fractionation of electron-transport chain of Escherichia coli. Biochimica et biophysica acta 357, 215-230.
KRINSKY, N. I. (1979). Carotenoid protection against oxidation. Pure and Applied Chemistry 51, 649-660.

Markwell, A. M., Suzanne, K., Hass, M., Bieber, L. L. \& Tolbert, N. E. (1979). Modification of the Lowry procedure to simplify protein determination in membrane and lipoprotein samples. Analytical Biochemistry 87, 206-210.

Nelson, L. M. \& KNowles, R. (1978). Effect of oxygen and nitrate on nitrogen fixation and denitrification by Azospirillum brasilense grown in continuous culture. Canadian Journal of Microbiology 24, 13951403.

Nur, I., OKon, Y. \& Henis, Y. (1980). Comparative studies of nitrogen-fixing bacteria associated with grasses in Israel with Azospirillum brasilense. Canadian Journal of Microbiology 26, 714-718.

NUR, I., SteinitZ, Y. L., OKON, Y. \& HenIS, Y. (1981). Carotenoid composition and function in nitrogenfixing bacteria of the genus Azospirillum. Journal of General Microbiology 122, 27-32.

OKON, Y., AlbreChT, S. L. \& BURRIS, R. H. (1976a). 
Factors affecting growth and nitrogen fixation of Spirillum lipoferum. Journal of Bacteriology 127, 1248-1254.

OKon, Y., Albrecht, S. L. \& BurRis, R. H. (1976b). Carbon and ammonia metabolism of Spirillum lipoferum. Journal of Bacteriology 128, 592-597.

OKon, Y., CaKmakcI, L., NuR, I. \& CheT, I. (1980). Aerotaxis and chemotaxis of Azospirillum brasilense. Microbial Ecology 6, 277-280.

OKon, Y., Houchins, J. P., AlBrecht, S. L. \& BurRis, R. H. (1977). Growth of Spirillum lipoferum at constant partial pressures of oxygen and the properties of its nitrogenase in cell-free extracts. Journal of General Microbiology 98, 87-93.

RotTEM, S. \& MARKowITZ, O. (1979). Carotenoids act as reinforcers of Acholeplasma laidlawii lipid bilayer. Journal of Bacteriology 140, 944-948.

Senior, P. J., Beech, G. A., Ritchie, G. A. F. \& DAwES, E. A. (1972). The role of oxygen limitation in the formation of poly- $\beta$-hydroxybutyrate during batch and continuous culture of Azotobacter beijerinckii. Biochemical Journal 128, 1193-1201.
Stern, A. I., Schiff, J. A. \& Epstein, H. T. (1964). Studies of chloroplast development in Euglena. V. Pigment biosynthesis, photosynthetic oxygen evolution and carbon dioxide fixation during chloroplast development. Plant Physiology 39, 200-226.

Stone, R. W. \& Wilson, P. W. (1952). Respiratory activity of cell-free extracts from Azotobacter. Journal of Bacteriology 63, 605-617.

Stouthamer, A. H., de VRies, W. \& Niekus, H. G. D. (1979). Microaerophily. Antonie van Leeuwenhoek 45, 5-12.

TARRAND, J. J , KRIEG, N. R. \& Döbereiner, J. (1978). A taxonomic study of the Spirillum lipoferum group, with description of a new genus Azospirillum gen. nov. and two species, Azospirillum lipoferum (Beijerinck) comb. nov. and Azospirillum brasilense sp. nov. Canadian Journal of Microbiology 24, 967-980.

Ward, A. C., Rowley, B. I. \& Dawes, E. A. (1977). Effect of oxygen and nitrogen limitation on poly- $\beta$ hydroxybutyrate biosynthesis in ammonium-grown Azotobacter beijerinckii. Journal of General Microbio$\log y$ 102, 61-68. 